\title{
Field study on nematode resistance in Nelore-breed cattle
}

\author{
P.A. Bricarello ${ }^{\text {a,* }}$, L.G. Zaros ${ }^{\text {b }}$, L.L. Coutinho ${ }^{\text {b }}$, R.A. Rocha ${ }^{\text {a }}$, F.N.J. Kooyman ${ }^{\text {c }}$, \\ E. De Vries ${ }^{\text {c }}$, J.R.S. Gonçalves ${ }^{d}$, L.G. Lima ${ }^{d}$, A.V. Pires ${ }^{b}$, A.F.T. Amarante ${ }^{a}$ \\ ${ }^{a}$ UNESP, Universidade Estadual Paulista, Departamento de Parasitologia, Instituto de Biociências, \\ Caixa Postal 510, Botucatu, CEP 18618-000, SP, Brazil \\ ${ }^{\mathrm{b}}$ Escola Superior de Agricultura Luiz de Queiroz-ESALQ/USP, Departamento de Zootecnia, Piracicaba, SP, Brazil \\ ${ }^{\mathrm{c}}$ Departament of Infectious Diseases and Immunology, Utrecht University, Utrecht, The Netherlands \\ ${ }^{\mathrm{d}}$ Estação Experimental Agrozootécnica Hildegard Georgina Von Pritzelwitz, FEALQ, Esalq, Londrina, PR, Brazil \\ Received 16 January 2007; received in revised form 30 May 2007; accepted 12 June 2007
}

\begin{abstract}
The present study evaluated Nelore cattle with different degrees of resistance to natural infections by gastrointestinal nematodes. One hundred weaned male cattle, 11-12 months of age, were kept on the same pasture and evaluated from October 2003 to February 2004. Faecal and blood samples were collected for parasitological, haematological and immunological tests. In February 2004, the 10 most resistant and the 10 most susceptible animals were selected based on individual means of nematode faecal egg counts (FEC). Such animals were slaughtered for worm burden determination and nematode species identification. The repeatability estimates for FEC ( \pm S.D.), log-transformed FEC and packed-cell volume (PCV) in all animals were $0.3( \pm 0.05), 0.26( \pm 0.04)$ and $0.42( \pm 0.05)$, respectively. The resistant group showed lower FEC and worm burdens than the susceptible group $(P<0.05)$. There were no significant differences between groups regarding mean body weight, weight gain, PCV and total serum protein values $(P>0.05)$. The resistant group showed higher total serum $\operatorname{IgE}$ levels $(P<0.05)$ and higher mean eosinophil blood counts. However, the latter was statistically significant only 42 days after the beginning of the study. Nematodes Cooperia punctata and Haemonchus place $i$ were predominant and the correlation between Cooperia and Haemonchus burdens was $0.64(P<0.05)$, which indicated that animals presenting increased numbers of one of those genera probably had increased numbers of the other. The current study provides further evidence of IgE active role in nematode immunity and suggests that total serum IgE level might serve as an additional marker to select Nelore cattle that are responsive to H. placei and C. punctata infections.
\end{abstract}

(C) 2007 Elsevier B.V. All rights reserved.

Keywords: Cattle; Cooperia; Haemonchus; Oesophagostomum; Nelore breed; IgE; Resistance

\section{Introduction}

Most beef cattle raised in Brazil belong to Nelore breed (Bos indicus). These Zebu cattle were brought to Brazil from Asia in the 18th century (Santiago, 1986) and showed excellent adaptation to the environmental

\footnotetext{
* Corresponding author. Tel.: +55 1438116239 ; fax: +551438153744 .

E-mail address: bricarellopa@yahoo.com.br (P.A. Bricarello).
}

and husbandry conditions found in most Brazilian states. In addition, this breed of cattle is highly resistant to tick (Boophilus microplus) infestation.

Parasite control mainly relies on anthelmintic treatment but the increasing demand for chemical-free animal products and the development of anthelmintic resistance to several chemical groups in parasites require new control strategies like the selection of resistant hosts.

The most used method to identify resistant hosts is still faecal egg counts (FEC), which is directly related to 
worm number and parasite fecundity (Sonstegard and Gasbarre, 2001). Studies using cattle in tropical areas have also indicated a significant correlation between FEC and total worm burdens (Bryan and Kerr, 1989).

Several studies in sheep have shown that immunoglobulin (Ig) $\mathrm{E}$ and eosinophil levels are also associated with parasite resistance. IgE production is generally considered an important factor in the host response to helminth infection (Miller, 1996). Bendixsen et al. (2004) showed that antigen-specific levels of IgE were significantly higher in genetically resistant lambs, compared with genetically susceptible lambs, after infection by Trichostrongylus colubriformis. Pettit et al. (2005) selected 10 responsive and 10 nonresponsive lambs among a Scottish Blackface flock infected with Teladorsagia circumcincta and found a larger number of circulating IgE-bearing cells in the blood of responsive lambs than in that of nonresponsive lambs.

Some studies in cattle have measured serum IgE levels following natural infections (Baker and Gershwin, 1992; Miller et al., 1996). The results obtained were not consistent but, in general, serum IgE levels increased after mild helminth infections. In a study about Dictyocaulus viviparous infection in calves, IgE levels were higher in animals previously infected than in non-infected controls from day 14 onwards. Among the lungworm-infected group, there was a significant correlation between total serum IgE levels and protection from 2 to 4 weeks after infection (Kooyman et al., 2002).

The present study aimed at identifying resistant and susceptible young Nelore cattle exposed to natural infection by gastrointestinal nematodes. Resistant and susceptible groups were compared regarding worm burden, PCV, weight gain, number of blood eosinophils, total plasma protein and IgE levels in the animals' sera.

\section{Material and methods}

\subsection{Animals and experimental design}

One hundred Nelore young bulls were evaluated. They were raised in a farm located at Londrina, Paraná State, south of Brazil (longitude $23^{\circ} 18^{\prime} 37^{\prime \prime} \mathrm{S}$, latitude $51^{\circ} 09^{\prime} 46^{\prime \prime} \mathrm{W}$, average annual temperature $21.3^{\circ} \mathrm{C}$ and rainfall in all seasons). Animals were born in November and December 2002. They were kept on 79 ha (divided into four paddocks) of Panicum maximum pasture, which was naturally contaminated by nematode larvae. The bulls were subjected to the farm's usual sanitary and nutritional management. They were treated with doramectin $\left(200 \mu \mathrm{g} / \mathrm{kg}\right.$; Dectomax ${ }^{\circledR}$, Pfizer) soon after birth to prevent myiases and were vaccinated against clostridiosis twice (Fortress ${ }^{\circledR}$, Pfizer; in March 2003 and June 2003). At weaning, around 6 or 7 months of age, they received anthelminthic treatment with ivermectin (Ivomec Gold ${ }^{\mathbb{R}}$, Merial) and were vaccinated against foot and mouth disease.

At the beginning of the experimental observations (October 31, 2003), animals were between 11 and 12 months of age. All bulls were kept on the same pasture and did not receive any additional anthelminthic treatment until the end of the study (February 19, 2004).

\subsection{Measurements}

Each animal was weighed and faecal and blood samples collected fortnightly. Based on the mean FEC obtained from October 31, 2003 to January 26, 2004, the 10 most resistant (i.e. those presenting the lowest mean FEC) and the 10 most susceptible animals (i.e. those presenting the highest mean FEC) were selected for worm burden determination and designated as resistant group and susceptible group, respectively. The selected animals were planned to be sacrificed immediately after the determination of FEC in January 26; however, problems in the slaughterhouse led to the postponement of the sacrifice until February 20, 2004.

\subsubsection{Parasitology}

Faecal samples were collected directly from the rectum for FEC determination, which was carried out using a modified McMaster technique (Ueno and Gonçalves, 1998). Infective larvae were identified according to descriptions of Keith (1953).

At necropsy, the abomasum and the small and large intestines were removed, opened, and their contents placed in a graduated bucket. A 5\% aliquot was preserved in 5\% formalin for subsequent enumeration and identification of nematodes into genus based on their morphology (Amarante et al., 1997; Ueno and Gonçalves, 1998). All adult males present in the aliquots were identified to species based on the morphology of their spicules.

\subsubsection{Haematology}

Blood samples with and without anticoagulant (EDTA) were collected through jugular vein puncture fortnightly from November 17, 2003 to January 26, 2004. Packed cell volume (PCV) was determined using the microhematocrit method and total serum protein levels were assessed using a refractometer (Refractometer SPR-N, Atago). Serum samples were stored at $-20{ }^{\circ} \mathrm{C}$ 
until use for immunoglobulin measurements. Eosinophil counts from peripheral blood were carried out in a Newbauer's chamber after Carpentier's solution staining (Dawkins et al., 1989) and expressed as number of cells per $\mu$ l blood.

\subsubsection{Serology—enzyme-linked immunosorbent assay (ELISA) for IgE antibody}

Total IgE levels in the animals' sera were measured using sandwich ELISA as previously described (Kooyman et al., 2002).

\subsection{Statistical analysis}

Repeatability for FEC and PCV was estimated over time (Giannoni and Giannoni, 1987). Animals that had missing FEC or PCV data were excluded from the analysis. The total number of animals evaluated for repeatability was 91 (FEC) and 95 (PCV).

Significant differences between the resistant and the susceptible group regarding FEC, PCV, body weight, worm burden, number of blood eosinophils, total serum protein and IgE levels were assessed through analysis of variance using the General Linear Model (GLM) of the Statistical Analysis Systems Institute (SAS, 1989). Faecal egg counts, worm burden, eosinophil counts and total IgE levels were transformed using $\log _{10}(x+1)$ to stabilise variance before the analysis. Relationships among the transformed data were established using Pearson's correlation.

Results were expressed as arithmetic means ( \pm standard deviation) of non-transformed data.

\section{Results}

\subsection{Parasitology}

The repeatability estimates for FEC ( \pm S.D. $)$ and logtransformed FEC were $0.3( \pm 0.05)$ and $0.26( \pm 0.04)$, respectively. The frequency distribution of individual mean FEC of 100 animals is presented in Fig. 1. Throughout the study, most of the animals (55\%) showed individual mean FEC lower than 200 eggs/g (EPG), whereas only $14 \%$ animals had mean FEC higher than 500 EPG.

Animals of the resistant group showed lower FEC than those of the susceptible group $(P<0.05)$ (Fig. 2). The resistant group showed FEC mean values lower than 50 throughout the experimental period, except on the slaughter day when up to 195 EPG were observed. The susceptible group presented means FEC constantly

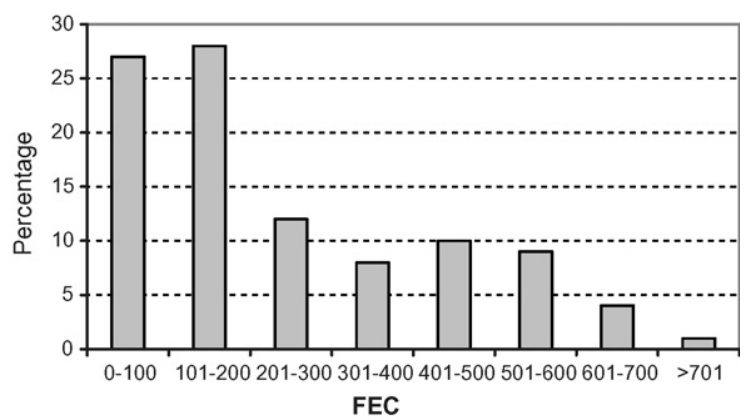

Fig. 1. The percent distribution of individual mean of faecal egg counts (FEC) of 100 Nelore young cattle. Data obtained fortnightly from October 31, 2003 to January 26, 2004

higher than 400 EPG and a peak was noticed on the 14th day.

In most of the experimental weeks, Cooperia spp. was the predominant genus found in composite cultures followed by Haemonchus spp. and Oesophagostomum spp. Larvae from the latter were identified in the cultures from the 14th day onwards showing higher percentages in the last weeks of the study.

The resistant group showed lower mean Haemonchus spp. and Cooperia spp. burdens than the susceptible group (Table 1). The estimated mean numbers of Haemonchus placei and Haemonchus similis were, respectively, 98.8 and 41.2 in the resistant group and 1092.4 and 127.6 in the susceptible group. In average, 1493.3 Cooperia punctata and 6.7 Cooperia pectinata specimens were found in the resistant group and 4778.5 C. punctata, 19.7 Cooperia spatulata and $6.8 \mathrm{C}$. pectinata in the susceptible group.

Oesophagostomum radiatum was the main parasite present in the large intestine of both groups at similar

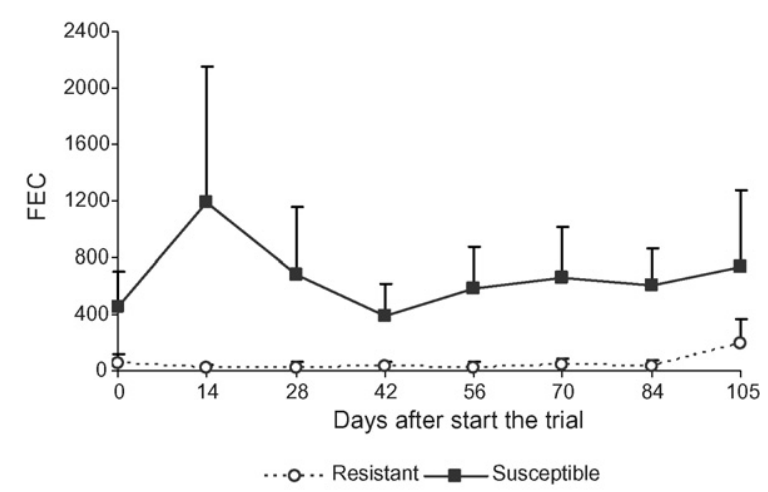

Fig. 2. Means of faecal egg counts (FEC) of the resistant $(n=10)$ and susceptible $(n=10)$ groups of Nelore cattle, naturally infected with gastrointestinal nematodes. Data obtained from October 31, 2003 to February 20, 2004, day of the sacrifice of the animals. Bars are standard deviation. There was a significant $(P<0.05)$ difference between the groups on all data. 
Table 1

Mean number of nematodes in the resistant $(n=10)$ and susceptible $(n=10)$ groups of Nelore young bulls naturally infected by gastrointestinal nematodes

\begin{tabular}{|c|c|c|c|}
\hline Nematodes & Resistant & Susceptible & Significance \\
\hline \multicolumn{4}{|l|}{ Haemonchus spp. } \\
\hline Adults & $140(0-285)$ & $1220(0-2679)$ & \multirow[t]{2}{*}{$* *$} \\
\hline Immatures & $16(0-80)$ & $52(0-200)$ & \\
\hline Total burden-abomasum & $156(0-380)$ & $1272(80-3400)$ & $* *$ \\
\hline \multicolumn{4}{|l|}{ Cooperia spp. } \\
\hline Adults & $1500(0-7620)$ & $4805(20-12,260)$ & \multirow[t]{2}{*}{ * } \\
\hline Immatures & 0 & $2(0-20)$ & \\
\hline Total burden-small intestine & $1500(0-7620)$ & $4807(20-12,260)$ & * \\
\hline \multicolumn{4}{|l|}{ Oesophagostomum spp. } \\
\hline Adults & $100(0-260)$ & $174(0-760)$ & \\
\hline \multicolumn{4}{|l|}{ Trichuris spp. } \\
\hline Adults & $20(0-40)$ & $12(0-20)$ & \\
\hline Immatures & $2(0-20)$ & $10(0-60)$ & \\
\hline Total burden-large intestine & $122(0-280)$ & $196(60-760)$ & \multirow[b]{2}{*}{ * } \\
\hline Total worm burden & $1778(40-7800)$ & $6275(160-13,900)$ & \\
\hline
\end{tabular}

Minimum and maximum values are in parenthesis. Significant differences between worm burdens of different groups are indicated.

${ }^{*} P<0.05$.

** $P<0.01$.

quantities: in average 100 in the resistant group and 174 in the susceptible group. Small numbers of Trichuris globulosa and Trichuris discolor were recorded without any significant difference between groups.

\subsection{Haematology, serology and body weight}

Nematode infection was asymptomatic even in susceptible animals. No differences between groups were noticed regarding mean PCV and total serum protein values (Fig. 3). The repeatability estimate for PCV was $0.42( \pm 0.05)$. Body weight increased throughout the study (Fig. 4). No significant differences between groups were observed regarding mean body weight and weight gain.

The resistant group presented higher blood eosinophil counts $(2294 \pm 945)$ on the 42nd day, compared with the susceptible group $(930 \pm 945)(P<0.05)$ (Fig. 5). In all experimental weeks, the resistant group had significantly higher total serum IgE levels compared with the susceptible group (Fig. 6).

\subsection{Correlations}

The correlation coefficients regarding FEC (logtransformed), weight gain and PCV which were calculated using data from 100 animals at every sampling time were, in general, close to zero. A significant correlation coefficient was only found between FEC and
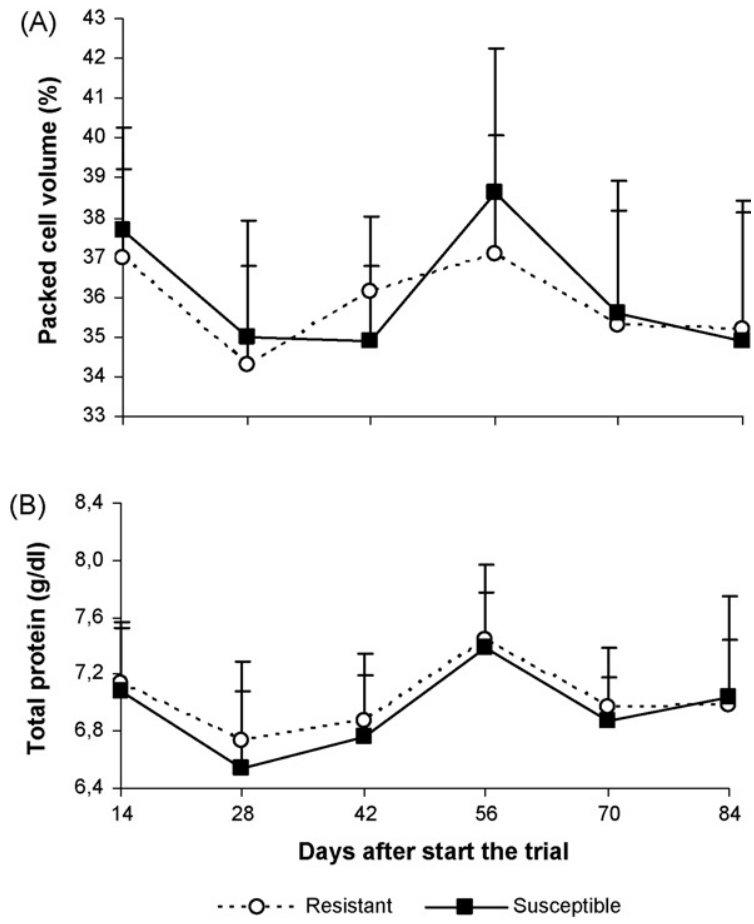

Fig. 3. Arithmetic means of (A) packed cell volume and (B) total plasma protein of the resistant $(n=10)$ and susceptible $(n=10)$ groups of young Nelore bulls naturally infected with gastrointestinal nematodes. Bars are standard deviation. No significant $(P<0.05)$ difference was found between the groups. 


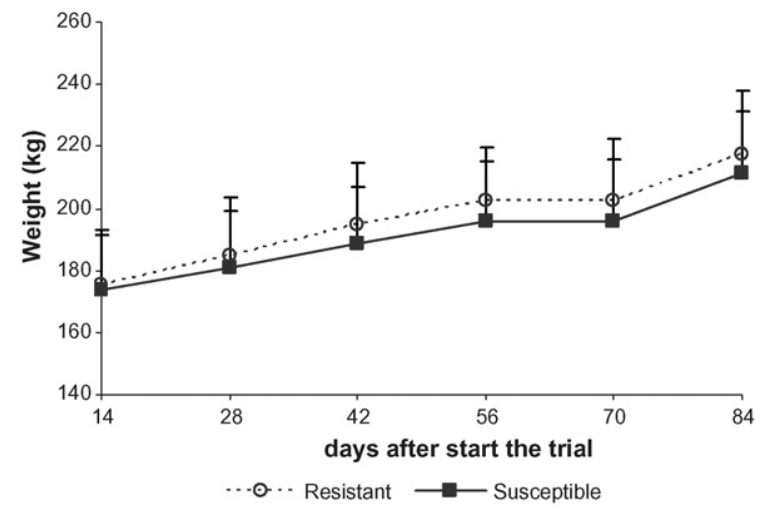

Fig. 4. Arithmetic means of body weight $(\mathrm{kg})$ of the resistant $(n=10)$ and susceptible $(n=10)$ groups of Nelore cattle, naturally infected with gastrointestinal nematodes. Bars are standard deviation. No significant $(P<0.05)$ difference was found between the groups.

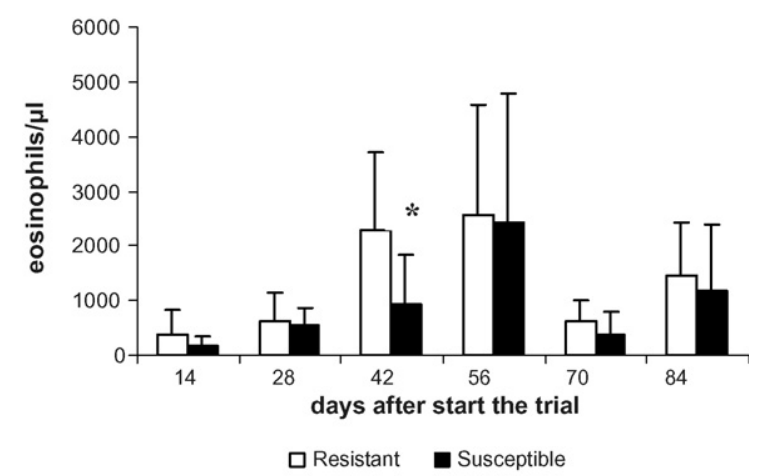

Fig. 5. Means of blood eosinophils of the resistant $(n=10)$ and susceptible $(n=10)$ groups of Nelore cattle naturally infected with gastrointestinal nematodes. Bars are standard deviation. Data on which a significant $(P<0.05)$ difference was found between the groups are indicated with an asterisk $(*)$.

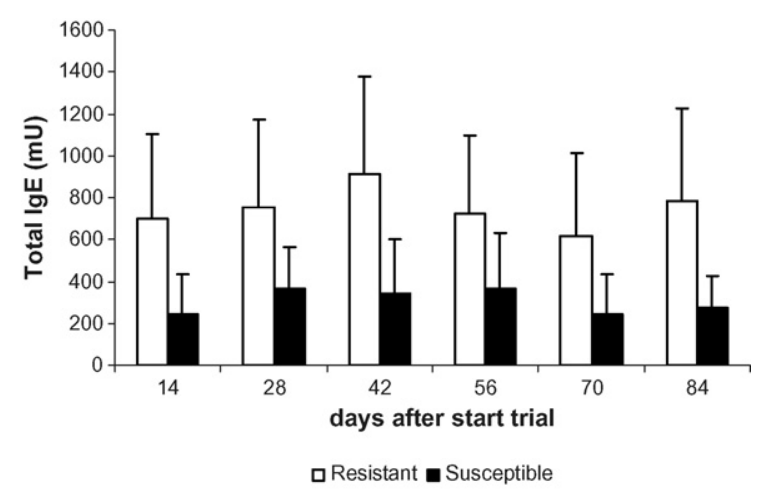

Fig. 6. Means of total $\operatorname{IgE}$ concentration in sera of the resistant $(n=10)$ and susceptible $(n=10)$ groups of Nelore cattle naturally infected with gastrointestinal nematodes. Bars are standard deviation. There was a significant difference between the groups on all data $(P<0.05)$.
PCV on the 14th day $(r=0.21 ; P<0.05)$. Analysing the 20 selected animals, correlation coefficients between the worm burdens of the two major parasites (Haemonchus and Cooperia, $r=0.64 ; P<0.05$ ) and between FEC and total worm burdens $(r=0.47 ; P<0.05)$ were positive, whereas the correlation between IgE levels and total worm burdens was negative $(r=-0.42 ; P=0.06)$.

\section{Discussion}

Parasite burdens have generally been over-dispersed, and negative binomial distribution has provided a good empirical description of dispersed distributions: most hosts carry few parasites, whereas a few heavily infected hosts harbour a large proportion of the total parasite population (Barger, 1989). Such over-dispersed pattern was clearly observed in the present study corroborating a previous experiment using Nelore young cattle (Nicolau et al., 2002).

No clinical signs of gastrointestinal infections or accentuated weight loss were noticed, and there was no association among FEC, PCV and weight gain. Similarly, Nicolau et al. (2002) did not notice any association among those variables in naturally infected Nelore cattle. In another study carried out in Australia using crossbred Zebu animals, there was a low correlation between resistance to parasites and growth (Mackinnon et al., 1991).

In the current study, the resistant group showed FEC mean values lower than 50 throughout the experimental period, except on the slaughter day when FEC reached 195 EPG. As the animals were kept without solid food for $24 \mathrm{~h}$ before slaughter, eggs were probable more concentrated in a smaller amount of intestinal contents.

The repeatability value obtained for FEC $(0.3)$ was similar to the values found by Stear et al. (2000) in sheep and by Mackinnon et al. (1991) in crossbred Zebu and Nicolau et al. (2002) in Nelore cattle naturally infected with nematodes. Repeatability for PCV (0.42) could be considered moderate and thus could be used together with the FEC to monitor nematode infections. This value was similar to the results obtained by Bekele et al. (1992) in sheep.

C. punctata and H. placei were the predominant parasites found in cattle, which agrees with previous studies carried out in Brazil (Guimarães et al., 1990; Lima, 1998; Nicolau et al., 2002) and in other tropical countries (Durie, 1962; Bryan and Kerr, 1989). Correlation coefficients between those parasites were positive, demonstrating that animals with increased numbers of one genus probably had increased numbers of the other. Stear et al. (1998) and Amarante et al. 
(2004) found similar results in naturally infected sheep. Such association indicates that the selection for resistance to one of the species will consequently improve the resistance to the other. With regard to the association involving other species found, the results were not conclusive because the numbers of such species were relatively low.

Results indicated that even breeds well-adapted to the tropics include individuals susceptible to nematode infections, presenting high worm burdens that result in increased pasture contamination and, consequently, in a higher degree of herd exposure to the parasites. Selecting gastrointestinal parasite-resistant animals may be an efficacious alternative for the prophylaxis of gastrointestinal nematode infections, minimizing the need for anthelminthic treatments, thus reducing the rate of development of anthelmintic resistance in the parasites. Such problem has been reported in countries that use pasture systems to raise beef cattle, including New Zealand (Vermunt et al., 1995) and Argentina (Fiel et al., 2001). A recent Brazilian study in cattle indicated the presence of Cooperia spp. and Haemonchus spp. resistant to several anthelmintics, particularly ivermectin (Soutello, 2005).

Not only FEC but also total serum IgE level was associated with the resistance degree, corroborating the results obtained by Kooyman et al. (1997) and Pettit et al. (2005) in sheep. Therefore, the present study provides further evidence of a role of $\mathrm{IgE}$ in nematode immunity and suggests that total serum IgE level might serve as an additional marker for selecting Nelore cattle that are responsive to $H$. placei and $C$. punctata infections.

\section{Acknowledgments}

This study was funded by Fundação de Amparo à Pesquisa do Estado de São Paulo, Brazil (FAPESP, Grant number 2004/03625-2) and by Department of Infectious Diseases and Immunology, Veterinary Faculty, Utrecht University, The Netherlands. P.A. Bricarello (Grant number 2003/13270-4) and L.G. Zaros (Grant number 2002/11568-3) received financial support from FAPESP.

\section{References}

Amarante, A.F.T., Bagnola Jr., J., Amarante, M.R.V., Barbosa, M.A., 1997. Host specificity of sheep and cattle nematodes in São Paulo state, Brazil. Vet. Parasitol. 73, 89-104.

Amarante, A.F.T., Bricarello, P.A., Rocha, R.A., Gennari, S.M., 2004. Resistance of Santa Inês Suffolk and Ile de France sheep to naturally acquired gastrointestinal nematode infections. Vet. Parasitol. 120, 91-106.

Baker, D.G., Gershwin, 1992. Seasonal patterns of total and Ostertagia-specific IgE in grazing cattle. Vet. Parasitol. 44, 211-221.

Barger, I.A., 1989. The statistical distribution of trichostrongylid nematodes in grazing lambs. Int. J. Parasitol. 15, 645-649.

Bekele, T., Kasali, O.B., Rege, J.E.O., 1992. Repeatibility of measurements of packed cell volume and egg count as indicators of endoparasite load and their relationship with sheep productivity. Acta Trop. 50, 151-160.

Bendixsen, T., Windon, R.G., Huntley, J.F., MacKellar, A., Davey, R.J., McClure, S.J., Emery, D.L., 2004. Development of a new monoclonal antibody to ovine chimeric $\operatorname{IgE}$ and its detection of systemic and local IgE antibody responses to the intestinal nematode Trichostrongylus colubriformis. Vet. Immunol. Immunopathol. 97, 11-24.

Bryan, R.P., Kerr, J.D., 1989. The relationship between the natural worm burden of steers and the faecal egg count differentiated to species. Vet. Parasitol. 30, 327-334.

Dawkins, H.J.S., Windon, R.G., Eagleson, G.K., 1989. Eosinophil responses in sheep selected for high and low responsiveness to Trichostrongylus colubriformis. Int. J. Parasitol. 19, 121-131.

Durie, P.H., 1962. Parasitic gastroenteritis of cattle: seasonal fluctuations of populations of strongyle larvae on a calf pasture and their significance in infection of the grazing animal. Aust. J. Agric. Res. 13, 776-777.

Fiel, C.A., Saumell, C.A., Steffan, P.E., Rodriguez, E.M., 2001. Resistance of Cooperia to ivermectin treatment in grazing cattle of the humid pampa Argentina. Vet. Parasitol. 97, 211-217.

Giannoni, M.A., Giannoni, M.L., 1987. Genética e melhoramento de rebanhos nos trópicos. Nobel, São Paulo, p. 473.

Guimarães, M.P., Costa, H.M.A., Lima, W.S., 1990. Prevalence of Cooperia punctata, C. pectinata and C. oncophora infections in dairy calves in Brazil. J. Helminthol. 64, 319-322.

Keith, R.K., 1953. The differentiation of infective larvae of some common nematode parasites of cattle. Aust. J. Zool. 1, 223-235.

Kooyman, F.N.J., Van Kooten, P.J.S., Huntley, J.F., MacKellar, A., Cornelissen, A.W.C.A., Schallig, H.F.H.S., 1997. Production of a monoclonal antibody specific for ovine immunoglobulin $\mathrm{E}$ and its application to monitor serum $\operatorname{IgE}$ responses to Haemonchus contortus infection. Parasitology 114, 395-406.

Kooyman, F.N., Yatsuda, A.P., Ploeger, H.W., Eysker, M., 2002. Serum immunoglobulin E response in calves infected with the lungworm Dictyocaulus viviparus and its correlation with protection. Parasite Immunol. 24, 47-56.

Lima, W.S., 1998. Seasonal infection pattern of gastrointestinal nematodes of beef cattle in Minas Gerais State-Brazil. Vet. Parasitol. 74, 203-214.

Mackinnon, M.J., Meyer, K., Hetzel, D.J.S., 1991. Genetic variation and covariation for growth, parasite resistance and heat tolerance in tropical cattle. Livest. Prod. Sci. 27, 105-122.

Miller, H.R.P., 1996. Prospects for the immunological control of ruminant gastrointestinal nematodes: natural immunity, can it be harnessed? Int. J. Parasitol. 26, 801-811.

Miller, J.E., Baker, D.G., Gersgwin, L.J., Canalas, J., Kearney, M.T., 1996. Serum IgE levels in dairy calves: evaluation of parasite and pasture exposure as possible determinants of IgE response. Vet. Parasitol. 63, 337-343.

Nicolau, C.V.J., Amarante, A.F.T., Rocha, G.P., Godoy, W.A.C., 2002. Relação entre desempenho e infecções por nematódeos gastrintestinais em bovinos Nelore em crescimento. Arq. Bras. Med. Vet. Zootec. 54, 351-357. 
Pettit, J.J., Jackson, F., Rocchi, M., Huntley, J.F., 2005. The relationship between responsiveness against gastrointestinal nematodes in lambs and the numbers of circulating IgE-bearing cells. Vet. Parasitol. 134, 131-139.

Santiago, A.A., 1986. O Zebu, na Índia, no Brasil e no mundo. Instituto Campineiro de Ensino Agrícola, São Paulo, p. 744.

SAS Institute Inc., 1989. SAS/STAT User's Guide. Version 6, fourth ed., version 2. SAS Institute Inc., Cary, NC, p. 943.

Sonstegard, T.S., Gasbarre, L.C., 2001. Genomic tools to improve parasite resistance. Vet. Parasitol. 101, 387-403.

Soutello, R., 2005. Eficácia de albendazol, levamisol, ivermectina e moxidectina em bovinos naturalmente infectados com helmintos gastrintestinais, no noroeste do Estado de São Paulo. Thesis (Doutorado). Universidade Estadual Paulista, FMVZ, Botucatu, $75 \mathrm{pp}$.
Stear, M.J., Bairden, K., Bishop, S.C., Gettinby, G., McKellar, Q.A., Park, M., Strain, S., Wallace, D.S., 1998. The processes influencing the distribution of parasitic nematodes among naturally infected lambs. Parasitology 117, 165-171.

Stear, M.J., Mitchell, S., Strain, S., 2000. The influence of age on the variation among sheep in susceptibility to natural nematode infection. Vet. Parasitol. 89, 31-36.

Ueno, H., Gonçalves, P.C., 1998. Manual para diagnóstico das helmintoses de ruminantes, fourth ed. Japan International Cooperation Agency, Tokyo, p. 143.

Vermunt, J.J., West, D.M., Pomroy, W.E., 1995. Multiple resistance to ivermectin and oxfendazole in Cooperia species of cattle in New Zealand. Vet. Rec. 137, 43-45. 